\title{
Anistia: os usos do passado contra os comunistas na Constituinte de 1946
}

\author{
Amnesty: uses of the past against communists in the Assembly of 1946
}

Amnistía: los usos del pasado contra los comunistas en la Constituyente de 1946

Mayara Paiva Souza*

\section{Resumo}

O texto pretende analisar a representação do tempo na Assembleia Nacional Constituinte de 1946. Para isso, utilizamos como fio condutor os debates acerca da Anistia naquela Assembleia. Os discursos referentes ao tema revelam a tensão entre lembrança e esquecimento, uma vez que os parlamentares, que se autodenominavam democratas, selecionavam o que deveria ser esquecido, ou não, por meio da anistia. Portanto, os debates revelam os temores e ressentimentos dos parlamentares que lutavam em duas frentes de batalha: o passado e o futuro.

Palavras-chave: Anistia. Constituinte de 1946. Memória.
A origem do termo Anistia remete-nos aos gregos. Desde a Grécia Antiga, a amnestía - esquecimento e redenção - tem sido usada para a conciliação e pacificação política. O primeiro registro de anistia na história data de 403 a.C. em Atenas. Após a deposição dos Trinta Tiranos, que ocupavam o poder desde a Guerra do Peloponeso, os cidadãos votaram em praça pública pela concessão de anistia a todos os envolvidos na guerra civil. Os excluídos foram repatriados após o juramento dos membros do tribunal ateniense: "juro não me lembrar do passado, nem consentir que outrem o lembre!" (MARTINS, 1978). Desse modo, percebemos que a sabedoria dos tratados de paz dos an-

\footnotetext{
Doutoranda em História pela Universidade Federal de Goiás. Pesquisa é financiada pela Fundação de Apoio à Pesquisa de Goiás (FAPEG).
}

Recebido em 26/08/2012 - Aprovado em 15/01/2013 http://dx.doi.org/10.5335/hdtv.13n.2.3716 
tigos gregos incluía a obrigação de esquecer os fatos que causaram um conflito e o que nele aconteceu.

Segundo Martins (1978), a anistia é, pela sua origem, irmã da democracia. Surgiu a partir das primeiras experiências democráticas em Atenas, estabelecendo regras de convivência dos contrários e respeito às oposições. A anistia era a forma de conciliar os interesses políticos em conflito para manter a unidade da comunidade. No entanto, a despeito da obrigação de esquecimento, legada pelos antigos gregos, algumas experiências não são facilmente esquecidas. Temos que admitir que muitas revoltas abrem feridas imensas no seio do grupo, dificultando a convivência entre vencedores e vencidos.

Este artigo tem como objeto o tema da anistia no contexto de redemocratização brasileira (1945-1946), mais especificamente, pretendo analisar como os debates sobre a anistia na Constituinte de 1946 envolveram um jogo de seleção entre o que seria lembrado ou esquecido do período Vargas. Essa negociação em torno da gestão da memória esteve marcada por disputas político-partidárias e afetivas acerca do passado. Nesse sentido, a bancada udenista e a comunista assumiram um primeiro plano no debate sobre a anistia na Constituinte, uma vez que eram partidos compostos, em sua maioria, por homens que vinham de lutas e perseguições durante o passado varguista.

O interesse está na constituição do quadro da memória a partir dos liames entre memória e esquecimento. Pretendo discutir, por intermédio dos debates sobre a anistia, os usos do passado pelos políticos que empreenderam a chamada "redemocratização brasileira". Parto do pressuposto de que o caráter do passado depende de como e de quanto ele é conscientemente apreendido no presente. Todavia, a necessidade de utilizar e reutilizar a memória, de recordar e esquecer é capaz de suscitar um complexo jogo de acomodação entre passado e presente (LOWENTHAL, 1998). É esse jogo entre a memória e o esquecimento que pretendo abordar no texto.

Os debates na Constituinte de 1946 revelam o temor da ameaça comunista no Brasil. A questão central nos debates sobre a anistia era: permitiriam, ou não, o regresso às Forças Armadas dos comunistas, os "traidores da Pátria", os "covardes que assassinaram colegas dormindo durante o levante de 1935"? ${ }^{1}$ Após a vitória dos Aliados na $2^{\text {a }}$ Guerra Mundial e o fortalecimento da União Soviética, após a libertação de Luiz Carlos Prestes e seus famosos discursos no Rio de Janeiro e São Paulo, após a eleição de 15 parlamentares comunistas para a Assembleia de 1946, os liberais udenistas da Constituinte perceberam que a ameaça não vinha apenas do retorno de Vargas ao poder, mas também do fortalecimento do comunismo. Portanto, os liberais teriam que combater em duas frentes de batalha: o passado e o futuro.

É essa tensão do tempo histórico que tento analisar neste texto; minha preocupação está em como os acontecimentos históricos foram lembrados pelos homens do período de redemocratização brasileira. O interesse maior está nos usos do passado para gerar sentido para o presente e o futuro. E para isso, o tema da anistia é um terreno fértil; uma vez que o próprio termo carrega o conflito entre a lembrança e o esquecimento na constituição do quadro da memória. 
0 debate sobre a anistia na Constituinte: as ameaças do passado e do futuro

Na sessão do dia 21 de março de 1946 o líder da UDN, Otávio Mangabeira, travou uma discussão com Luiz Carlos Prestes acerca do apoio dos comunistas a Getúlio Vargas em 1945:

O Sr. OTÁVIO MANGABEIRA - Durante a campanha democrática que fizemos na praça pública, sem medir esforços ou consequências, enfrentando a ditadura, V. Exa. nos abandonou, desprezando a causa democrática para fortalecer a ditadura, que era precisamente a reação (Palmas).

O Sr. Carlos Prestes - Havia, entre o Partido Comunista e a UDN, algo que os separava profundamente. [...] Éramos contra as tendências golpistas de V. Exas. [...] Na noite de 29 para 30 de outubro, quando o Sr. Brigadeiro Eduardo Gomes, junto com o General Dutra, comandava o golpe, do Quartel General nesta Capital...

O Sr. OTÁVIO MANGABEIRA - Que nos libertou da ditadura...

O Sr. Carlos Prestes -... os tanques, os canhões, as metralhadoras não foram dirigidas contra o Sr. Getúlio Vargas, mas contra a sede do Partido Comunista. [...] Modificou-se por acaso a ditadura que vivíamos? Não. A situação continua a mesma. [...].

O Sr. OTÁVIO MANGABEIRA - Não fora o golpe de 29 de outubro e estaríamos, até hoje, nas garras da ditadura que V. Exa. apoiou. (Palmas). Esta, a minha queixa. [grifos meus] (ANC, 21/03/1946, p. 257-258).

As queixas e ressentimentos de Mangabeira demonstram que Prestes e seu grupo, na perspectiva udenista, estavam marcados pela "perfídia". Porém, não eram apenas os parlamentares da UDN os únicos antico- munistas na Constituinte. O PCB era um partido indesejado na Assembleia, o "corpo estranho", o que, para os parlamentares, amava a desordem e o partido estrangeiro que não atendia aos interesses da Nação.

Instigados sobre o seu passado de "crimes" contra a Pátria, os comunistas, representados por Carlos Marighela, se pronunciaram na Constituinte:

Anistia é esquecimento. Sobre tudo isso se passou uma esponja [...] Aqueles que nos perseguiram, que nos acusaram, que levantaram tantas infâmias contra nós, acabaram recuando e, ante o decreto de anistia, reconheceram que não tinham nenhuma razão, para nos atacar. Sr. Presidente, anos depois, uma vez tudo sanado, quando estamos num ambiente de democracia, com partido legalmente organizado, com representantes dentro desta Assembleia, ainda se repetem aqui, aqueles velhos argumentos que não tem mais nenhum valor, e nos quais ninguém mais acredita.(ANC, 28/02/1946, p. 15).

Marighela estava equivocado, não haviam "passado a esponja" ou sanado o passado. A anistia de 1945 não havia apagado os "crimes" dos comunistas. O Decreto-lei de 18 de abril daquele ano apenas teria colocado os comunistas em liberdade, mas o passado não havia sido apagado, a "ameaça vermelha" não havia sido banida da memória, pelo contrário, estava cada vez mais presente e os usos do passado na Constituinte trariam à tona os acontecimentos pretéritos.

Em um ponto Marighela tinha razão, anistia é esquecimento, é apagar os rastros de um delito e bani-lo da memória. O passado anistiado torna-se "proibido" em prol de uma reconciliação entre as partes, entretanto, por ser a anistia um esquecimento insti- 
tucional, muitas vezes o "passado proibido" continua no âmbito da consciência histórica. Enquanto esquecimento institucional, a anistia toca nas raízes do político. Como destacou Paul Ricoeur, a anistia é um "esquecimento obrigado", um esquecimento que, embora legal, não é legítimo, pois, na maioria das vezes, é imposto e não desejado, para o autor, a anistia cala o mal e priva a opinião pública do dissensus (2007). Embora funcione como terapia social emergencial, sob o signo da utilidade de se estabelecer uma paz cívica, a anistia é um esquecimento jurídico limitado (RICOEUR, 2007).

Os comunistas, mesmo "anistiados", em 1945, estavam fadados a carregarem o fardo do passado. Com os debates sobre a ampliação da anistia na Constituinte de 1946, os correligionários do PCB perceberam que nem mesmo no âmbito institucional o passado comunista fora banido. A "traição" dos comunistas ainda era um tema presente. Sobre a sobrevivência dessas lembranças, Pedro Luís, um observador dos trabalhos da Assembleia Constituinte escreveu:

Entre nós, no Brasil, vários e tenebrosos foram os crimes praticados, os quais vivem ainda hoje na memória de todos, causticando a consciência desses infelizes, desses desprezíveis criminosos, frios e desumanos, a ignominiosa chacina de 1935, da Praia Vermelha (LUIS, 1946, p. 94).

O homicídio de Elza Fernandes, o levante de 1935, o suposto assassinato de soldados legalistas que dormiam durante o levante no Rio de Janeiro e o apoio de Prestes a Vargas em 1945, eram ressaltados pelos Constituintes para evidenciarem o caráter "frio", "covarde" e "traiçoeiro" dos comunistas, aqueles que compunham a bancada indesejada da Assembleia².
Em março de 1946, o líder comunista, Luiz Carlos Prestes, cometeria uma nova "traição" à Pátria, segundo a perspectiva dos parlamentares e da imprensa anticomunista. Essa "traição" seria usada como pretexto para a restrição da anistia na Constituinte. O Senador Luiz Carlos Prestes prestou declarações que foram publicadas no jornal comunista Tribuna Popular. Em tal sabatina, Prestes afirmou que em caso de uma Guerra imperialista entre Brasil e União Soviéti$\mathrm{ca}$, os comunistas combateriam essa guerra dentro do Brasil:

Combateríamos uma guerra imperialista contra a URSS e empunharíamos armas para fazer a resistência em nossa Pátria contra um governo desses, retrógrado, que quisesse a volta do fascismo. Mas acreditamos que nenhum governo tentará levar o povo brasileiro contra o povo soviético, que luta pelo progresso e bem-estar dos povos. Se algum governo cometesse este crime, nós, comunistas, lutaríamos pela transformação da guerra imperialista em guerra de libertação nacional (apud ANC, 18/03/1946, p. 82).

As declarações de Luiz Carlos Prestes teriam passado despercebidas, pois essa não era a primeira vez que o comunista destacava sua posição acerca do tema. Entretanto, em 1946 o Partido Comunista - que elegera pela primeira vez uma bancada para a Assembleia Nacional Constituinte - estava inserido na arena política, elegera 15 parlamentares para a Assembleia e tomava parte na elaboração da nova Constituição que ditaria os rumos da Nação brasileira.

Nesse sentido, as declarações de um senador, integrante da bancada comunista na Constituinte, não poderiam passar sem serem notadas, uma vez que os olhos 
da Nação estavam voltados para a Assembleia Nacional Constituinte, além disso, os brasileiros depositavam as expectativas de transformação da Pátria nos parlamentares eleitos pelo povo em 2 de dezembro de 1945. Após quinze anos de governo Vargas, a Assembleia Constituinte era um símbolo de redemocratização do país, era o "espelho" da Nação. Com a deposição do ditador e a eleição de Eurico Gaspar Dutra para a presidência, a Assembleia era o espaço privilegiado para a defesa do liberalismo que não pretendia partilhar a liberdade política com os comunistas.

Em 2 de dezembro, o candidato da UDN, Brigadeiro Eduardo Gomes, fora derrotado nas urnas pelo candidato do governo, Eurico Gaspar Dutra. Além disso, o PSD, governista, elegera a maior bancada para a Assembleia Nacional Constituinte; restara a UDN, a segunda bancada, a minoria. A Assembleia Constituinte tornou-se um muro de lamentações para os udenistas que não conseguiram atingir o poder. Nesse sentido, seus discursos e projetos estavam voltados muito mais para o passado do que para o presente. Era preciso fortalecer a imagem negativa do passado varguista, da ditadura, portanto o passado era um instrumento de luta para o presente. Era necessário explicar a derrota nas urnas, apontar culpados e impedir que Getúlio Vargas, o político mais votado para a Constituinte, não retornasse ao poder.

Os udenistas combatiam em duas frentes: o passado e o futuro. O Estado Novo representava o passado arbitrário que era preciso punir para que, no futuro, Getúlio Vargas não retornasse. O comunismo repre- sentava a ameaça futura, uma vez que este se apresentava, pela primeira vez no Brasil, como um partido coeso e na legalidade. Além disso, após a participação da União Soviética na Segunda Guerra, o comunismo saiu fortalecido internacionalmente. Em 1946, mais do que nunca, a ameaça vermelha era iminente.

Para o jornalista Assis Chateaubriand, a Constituinte de 1946 enfrentava "dois sátiros", Getúlio Vargas e os comunistas:

A pucela democracia se vê assaltada, hoje na via pública por dois sátiros: um de barbas vermelhas, que é russo, e outro de capuz, que é o Encoberto de São Borja. O primeiro já se acha em ação franca promovendo com a ausência de tato que lhe é habitual, estripulias de todo tamanho com a pobre virgem inexperiente (CHATEAUBRIAND, 1999, p. 439).

Como destacou o jornalista, a democracia brasileira era uma "virgem inexperiente" que, de um lado, enfrentava a constante ameaça de retorno de um passado arbitrário e de outro, enfrentava a "maré vermelha", ou seja, a maré alta do comunismo. Portanto, mesmo que o presente não correspondesse com as expectativas dos liberais, o governo do General Eurico Dutra era visto como algo "menos ruim" do que o passado varguista ou a ameaça de um futuro comunista. Na sessão do dia 2 de agosto de 1946, o parlamentar Café Filho (PRP-RN) discursou na Assembleia sobre o tema:

Ninguém se iluda. Aí está um governo que ninguém quer derrubar... [...] Derrubar para que e por quê? O que viesse depois talvez fosse pior. Vamos consertar o que está aí. Tenho ouvido apelos: vamos juntar-nos, vamos reunir-nos, agremiar-nos porque há um perigo sobre todos nós - é de que o comunismo tome conta do Brasil (ANC, 02/08/1946). 
Como demonstra a fala de Café Filho, os Constituintes da Assembleia de 1946 estavam muito mais preocupados em combater as questões do passado e do futuro do que as questões do presente relativas ao governo Dutra. O presidente eleito governou, até a promulgação da nova Carta Constitucional em setembro de 1946, ancorado na Constituição de 1937. Dutra, muito mais do que Vargas, fez uso dos Decretos-lei previstos na Carta de 1937, porém seu autoritarismo era visto, por muitos contemporâneos, como algo necessário para combater a ameaça comunista.

Nesse contexto, as declarações de Luiz Carlos Prestes acerca de uma hipotética guerra imperialista que envolvesse Brasil e União Soviética, provocaram grande celeuma tanto no plenário da Constituinte quanto na imprensa brasileira. As declarações foram tomadas como pretexto para o combate ao comunismo, porém, esse pretexto foi usado também para a limitação das liberdades políticas e individuais na elaboração da nova Carta Constitucional. Os debates sobre a anistia na Constituinte de 1946 demonstram o alcance das declarações de Prestes e da ameaça comunista.

A marca da Constituinte de 1946 era a "democracia", no entanto o Decreto-lei ${ }^{\circ}$. 7.474 de 18 de abril de 1945, que concedeu anistia a todos quantos tinham cometido crimes políticos, desde 16 de julho de 1934 até a data de sua publicação, ainda não lograra entrar em plena vigência, devido às restrições ou exclusões que foram estabelecidas nos artigos $2^{\circ}$ e $3^{\circ}$. Esses artigos apresentavam restrições que deixavam os anistiados a critério de comissões criadas segundo a conveniência do regime. As soluções governamentais não eram imediatas e gerais e, quase um ano após o Decreto-lei da anistia, aqueles que deviam ser beneficiados ainda não sentiam seus efeitos.

O Deputado Federal Euclides Figueiredo, eleito pela legenda da UDN-DF, foi o primeiro a se pronunciar sobre o tema da anistia na Constituinte de 1946. Figueiredo fora um respeitado Coronel durante a $1^{\mathrm{a}} \mathrm{Re}-$ pública, porém, ao recusar a liderança militar do movimento revolucionário de 1930, esse Coronel fora preso e perseguido pelos vitoriosos da Revolução. Ressentido contra Getúlio Vargas, Figueiredo foi um dos líderes do movimento paulista de 1932; entretanto, com a derrota do movimento, coube-lhe o exílio em Lisboa. Anistiado em 1934, ele regressou ao Brasil e não cessou em fazer constante oposição à Vargas. Durante o Estado Novo Figueiredo fora preso e considerado morto por decreto ${ }^{3}$, mas o "morto" não cessara de se opor ao governo e, de dentro do cárcere, tomara parte na organização do Putsch Integralista de 1938. Após tantas perseguições e derrotas sofridas por Euclides Figueiredo, a anistia de 1945 veio a beneficiar também esse ferrenho opositor de Vargas. Eleito deputado em 1946, uma das suas principais preocupações seria a ampliação da anistia.

Na sessão de 18 de março de 1946, o udenista Euclides Figueiredo levou ao debate na Constituinte a Indicação $n^{\circ} .27$ de sua autoria. Euclides Figueiredo afirmou que a Constituinte de 1946 representava a esperança contra o totalitarismo no Brasil, portanto era necessário atingir os anseios dos diversos setores da vida nacional que ai- 
nda não tinham sido atingidos pelos ventos que "hão de levar, de vez, os últimos resquícios do estadonovismo" (ANC, 18/03/1946, p. 71).

Segundo o deputado udenista, era necessário suprimir os artigos $2^{\circ}$ e $3^{\circ}$ do Decreto-lei $n^{\circ} .7 .474$ de 18 de abril de 1945, uma vez que as Comissões criadas pelos dispositivos operavam com tal morosidade que a anistia vinha "pingando" de caso em caso, se assemelhando a mero indulto. Todavia, a indicação do udenista Euclides Figueiredo gerou um grande debate. Se a marca da Constituinte era a democracia e o rompimento com as arbitrariedades do Estado Novo, porque a maioria dos parlamentares não queria ampliar a anistia de 1945? Barreto Pinto (PTB), ao apartear o discurso de Euclides Figueiredo, nos dá a primeira pista para responder a questão. Conforme Barreto Pinto, a supressão dos artigos permitiria que oficiais que mataram seus colegas dormindo voltassem às fileiras do Exército.

Ao referir-se aos crimes, Barreto Pinto aludia aos comunistas acusados de matarem oficiais enquanto dormiam durante o levante de 1935. Apesar da acusação, os comunistas, que participaram do levante e foram julgados pelo Tribunal de Segurança Nacional, em 1936, não foram condenados por assassinatos de colegas que dormiam. Entretanto, apesar da ausência de provas, a versão propagou-se e a nódoa da traição acompanhou os comunistas revoltosos de 1935 ao longo da história. Em 1946, essa versão foi usada pelos parlamentares que se opunham à ampliação da anistia, uma vez que anistiar seria permitir que os "traidores" regressassem as fileiras das Forças Armadas.
Alcedo Coutinho, o comunista mais moderado da Constituinte, trouxe seu apoio ao requerimento de Euclides Figueiredo, pois, segundo o deputado comunista, a anistia era um ponto positivo para o processo de democratização e de união nacional. Alcedo Coutinho leu a entrevista de Prestes em 27 de abril de 1945, na qual o líder comunista em resposta à pergunta sobre se a anistia daquele ano era insatisfatória respondeu que a verdadeira anistia seria dada pelo parlamento eleito, com o reconhecimento dos direitos de todos os anistiados. Para Prestes, segundo Coutinho, o Decreto-lei 7.474 representou apenas a liberdade dos presos políticos; mas, naquela época, a anistia de 1945, representou uma conquista democrática.

Para Alcedo Coutinho era absurdo que os antigos oficiais comunistas, eleitos Deputados e Senadores para a "Casa do povo", continuassem sem autorização para a sua reversão aos antigos postos ocupados antes de 1935. De acordo com o deputado, a questão central dos debates acerca da ampliação, ou não, da anistia estava voltada para as Forças Armadas. Afinal, estas deveriam ser fiéis à Nação e formarem um corpo coeso de acordo com a hierarquia estabelecida. Todavia, a questão era: como inserir no bojo das Forças Armadas Brasileiras, o "germe" comunista que traiu a Nação e, consequentemente, as Forças Armadas em 1935?

O deputado Lino Machado da UDN-PR do Maranhão, tenente-coronel que havia apoiado a candidatura de José Américo de Almeida à presidência da República em 1937, tomando a palavra, afirmou que a anistia de 1945 não era medida que todos pleiteavam durante a campanha pró-anistia. 
Ao expressar seu apoio ao requerimento de seu colega de bancada Euclides Figueiredo, Lino Machado destacou sua opinião acerca da anistia concedida por Getúlio Vargas em 1945:

O Sr. ditador, entretanto, resolveu pôr em prática, como era de seu feitio, como era de seu modo de agir, apenas o perdão, perdão que seria dado aos amigos, àqueles que porventura se achassem ligados, de qualquer maneira, à ditadura. [...] continuam afastados das classes aramadas inúmeros oficiais que foram envolvidos tão só em movimentos políticos. Nenhum estava acusado de crime comum, entretanto, continuam oficialmente mortos [...] como se realmente eles não existissem. Sem dúvida, a situação é deprimente, excessivamente deprimente, para nossas classes armadas e, igualmente, deprimente para os funcionários civis afastados de seus cargos. [...] o próprio governo não praticou anistia, apenas concedeu perdão (ANC, 18/03/1946, p. 80).

Como destacou Lino Machado, perdão e anistia são termos diferentes. Anistia é um ato eminentemente político destinado a promover o esquecimento dos delitos e promover a paz. Segundo Roberto Ribeiro Martins (1978), a anistia surgiu a partir das necessidades políticas das experiências democráticas da Grécia antiga para estabelecer as regras de convivência dos contrários e do respeito ao "outro"; era uma fórmula usada pelos políticos para conciliarem interesses e manterem a unidade. A anistia é usada, geralmente, para esquecer crimes políticos. Em contrapartida o indulto geralmente é usado para perdoar crimes comuns. Perdoar, não é esquecer. Diferentemente da anistia que apaga os rastros do passado a ser esquecido, o perdão não bane os rastros da memória.
A condição em que se encontravam os "anistiados" de 1945, como destacou Lino Machado, demonstrava que o Decreto assinado por Vargas em abril daquele ano aproximava-se, muito mais, de um indulto, pois este apenas "perdoou" os presos e os colocou nas ruas, "perdoou" um "crime comum" e colocou cada caso sob a análise de Comissões que dariam um parecer posterior.

Portanto, a anistia de 1945 não foi coletiva, não anistiou apenas crimes políticos e não apagou os rastros dos delitos ao criar Comissões que julgariam cada caso individualmente. Ao nomear as Comissões, o governo perdoaria, segundo Lino Machado, apenas os "amigos".

Ao findar o discurso do deputado maranhense que demonstrou seu apoio ao requerimento de ampliação da anistia apresentado por Euclides Figueiredo, Nereu Ramos, líder do PSD, alegou que sua bancada votava contra o requerimento porque confiava que o governo cumpriria com as determinações do Decreto de anistia de 1945.

Nessa sessão de 18 de março, o tema da anistia se tornou um pretexto para expor a ameaça comunista e o perigo de reverter às fileiras das Forças Armadas aqueles que lideraram o Levante de 1935. O insucesso da indicação $n^{\circ} .27$ de Euclides Figueiredo deveu-se, principalmente, ao argumento utilizado pelo parlamentar Segadas Viana do PTB do Distrito Federal. Líder da bancada petebista do Distrito Federal, Segadas Viana foi um dos maiores defensores do legado do Estado Novo. Além de combater o comunismo e o PCB, era um ferrenho defensor do intervencionismo estatal e crítico virulen- 
to do liberalismo. Portanto, ao interferir no debate sobre a anistia, o antigo funcionário do Ministério do Trabalho durante o Estado Novo, foi o maior defensor da manutenção das Comissões nomeadas pelo presidente da República.

O líder da bancada do PTB/DF afirmou que não era possível manifestar-se em conjunto, visto que cada problema apresentava peculiaridades e estava em jogo a defesa e segurança nacional. Era necessária a prevenção do retorno às Forças Armadas de "certos elementos". Nesse ponto de seu discurso, Segadas Viana referia-se ao Senador Luiz Carlos Prestes que, anistiado em 1945, segundo o orador, representava perigo para a segurança nacional, uma vez que o líder comunista afirmara em entrevista à Tribuna Popular que em caso de uma guerra entre o Brasil e a União Soviética, os comunistas combateriam contra o Brasil.

De acordo com Segadas Viana, essas declarações do senador pecebista confirmavam que era necessário o estudo de cada caso, para verificar se era justo ou não trazer para o seio da Nação e das Forças Armadas elementos dispostos a combaterem contra a Pátria. Com esse discurso, o deputado do PTB lançou as bases do que geraria um longo debate nas sessões seguintes. A entrevista de Luiz Carlos Prestes ainda traria muitos problemas para o Partido Comunista.

Outro representante do PTB que se manifestou contra a indicação de Euclides Figueiredo foi Rui Almeida, uma vez que o requerimento daria ganho à causa comunista. O coronel Rui Almeida era um "ex-tenente" que recebera a anistia em 1930 por ter se levantado em armas contra o governo Ber- nardes (BRAGA, 1988). Apesar de ter sido anistiado, negou esse mesmo direito aos que aguardavam as decisões das Comissões sujeitas ao presidente da República. O deputado justificou o seu voto, afirmando que os comunistas eram inimigos da Pátria, traidores que jamais poderiam integrar as fileiras das Forças Armadas do Brasil.

Não podia, Sr. Presidente, depois do movimento comunista no Brasil, quando militares dormindo foram assassinados nos quartéis, (palmas) não podia, sem trair minha própria honra, minha dignidade de militar, aprovar esse requerimento. Não the negaria meu voto se não viesse dar ganho de causa aos comunistas. No Exército, na Marinha e na Aeronáutica de minha terra não há lugar para os inimigos da Pátria (palmas). Aqueles que traíram ontem, trairão amanhã! $\mathrm{E}$ os que não têm pejo de dizer que estão a soldo de Moscou, os que não se constrangem em declarar que, na hipótese de uma guerra entre o Brasil e a Rússia ficariam ao lado desta - esses nunca poderão pertencer às gloriosas forças armadas de minha terra. [grifos meus] (ANC, 18/03/1946, p. 86).

Após as manifestações contrárias ao requerimento de Figueiredo, Campos Vergal, em nome do Partido Republicano Progressista, apresentou voto a favor. Segundo o parlamentar, ao iniciar uma vida nova, o Brasil não deveria trazer para o presente $\mathrm{e}$ para a construção do futuro, uma herança de perseguições e de ódio, pois esses nada constroem. Para Campos Vergal, todos os oficiais eram igualmente dignos de serem revertidos às fileiras das Forças Armadas para contribuírem com a reconstrução da Nação. E destacou que o povo brasileiro tinha confiança no presente e no futuro do Brasil, portanto, ele não acreditava que 
ainda houvesse cidadãos capazes de trair o destino da Pátria. A anistia seria uma forma de o governo dar as mãos aos cidadãos que queriam contribuir com o ressurgimento da democracia brasileira.

O debate de 18 de março evidencia que a questão da anistia na Constituinte de 1946 levava os parlamentares a reinterpretarem o passado tendo em vista as questões do presente e do futuro. O presente anunciava um fortalecimento dos comunistas após a vitória dos aliados na Segunda Guerra; o futuro vinha carregado de expectativas e disputas de poder, nas quais, era necessário retirar dois adversários da cena política: Getúlio Vargas - inimigo dos udenistas - e os comunistas - "inimigos da Pátria", dos udenistas, dos petebistas, dos pessedistas, entre outros.

Na Assembleia Constituinte de 1946, as paixões e ressentimentos guiavam muitos dos parlamentares ali presentes. Entretanto, os comunistas mostravam-se indiferentes às questões pessoais e aos ressentimentos em relação ao passado varguista. Apesar das acusações e provocações ocorridas na sessão de 18 de março, quando Euclides Figueiredo levou ao debate a anistia, os comunistas demonstravam desinteresse e indiferença pelas questões pessoais e continuavam, em uníssona voz, defendendo a "União Nacional" para livrar a Pátria do imperialismo ianque.

Em 26 de março, após longo debate sobre o imperialismo e elogios à Rússia, Luiz Carlos Prestes foi aparteado por Juracy Magalhães, udenista baiano que tinha verdadeira repulsa ao comunismo:
Juraci Magalhães - Inquieta a todos nós, democratas e patriotas e, particularmente, a mim, pois, além do mais, sou militar, o seguinte: no caso de uma guerra a que for arrastado o Brasil, por força de obrigações internacionais, cumprindo o Governo os dispositivos constitucionais e legais que regerão a declaração de guerra, e no caso de ser a Rússia, nessa guerra, adversária do Brasil, o Senador Carlos Prestes e o Partido Comunista do Brasil lutarão pela sua Pátria ou iniciarão uma guerra civil? Esta a pergunta em toda a sua simplicidade.

SR. LUIZ CARLOS PRESTES - A pergunta de V. Ex a é capciosa.

Juraci Magalhães - Não é nada capciosa. Capcioso é o silêncio de V. Ex $x^{\mathrm{a}}$. [...]

SR. LUIZ CARLOS PRESTES - A declaração de minha entrevista está reafirmada muitas vezes. Ninguém mais pode ter dúvida. [...] E a resposta não podia ser surpresa para nenhum homem mais ou menos informado em nossa Pátria, porque essa é a atitude dos comunistas. Agora, o ilustre representante pelo estado da Bahia faz uma pergunta capciosa (ANC, 26/03/1946, p. 48-49).

Segundo Prestes, os parlamentares pretendiam dar uma interpretação perversa e mal intencionada à sua entrevista, uma vez que ele já havia dito e redito aquelas palavras sobre uma possível guerra imperialista que envolvesse Brasil e Rússia. Suas palavras não eram novidade, pois para os comunistas o patriotismo estava ligado à luta contra o imperialismo.

SR. CARLOS PRESTES - minhas declarações não podiam produzir essa celeuma, essa gritaria, esse coro de insultos de toda ordem, que infelizmente vieram, até dentro da Assembleia. Porque essa é uma velha posição dos comunistas, posição reafirmada muitas vezes por nós. Que há por 
trás dessas palavras? Que provocou a celeuma? Porque essa série de provocações, esses ataques pessoais, esses insultos, essa campanha anticomunista dos dias de hoje? Eles surgiriam com as minhas palavras ou sem as minhas palavras, de qualquer maneira, com qualquer pretexto, porque esse é o método usado pelos imperialistas no momento em que vivemos no mundo e em nossa Pátria: é a preparação para a guerra. E nos arranjos para a guerra é mister criar o ambiente, preparar psicologicamente, o povo para a luta, liquidar a democracia, tapar a boca dos homens com coragem de falar o que pensam e dizer as verdades dos homens que não se acovardam quando julgam ser preciso dizer, como eu disse, aquelas palavras. Na hora atual, tais provocações, tais ataques surgiriam de qualquer forma. Palavras como aquelas eu as pronunciei muitas vezes, poucas semanas antes e muitos meses passados também (ANC, 26/03/1946, p. 57).

Prestes afirmara que as provocações vinham dos reacionários que tentavam defender os interesses dos ianques no Brasil, esses atacavam o partido comunista para dividi-lo. Entretanto, segundo Prestes, o partido comunista era um verdadeiro monólito, indivisível que soubera sobreviver a vinte e três anos de clandestinidade, após torturas e lutas terríveis permanecera vivo, pronto para a luta (ANC, 26/03/1946 p. 57). Ao atacarem o partido comunista, conforme o Senador, os parlamentares atacavam a democracia e comprovavam que o anticomunismo nada mais era do que uma luta contra a democracia.

A entrevista de Prestes foi usada como pretexto para o fechamento do Partido Comunista no ano seguinte. Enfim, os anticomunistas tinham uma prova concreta - afirmada e reafirmada por Prestes - do "caráter traiçoeiro" da bancada Comunista em relação à Pátria, do estrangeirismo do partido e, principalmente, a entrevista de Prestes provara que o comunismo era um "vírus" que deveria ser combatido e eliminado das Forças Amadas e do Brasil.

Prestes tinha razão, suas palavras foram usadas como justificativa para a restrição das liberdades individuais. Sob o pretexto da ameaça comunista, a anistia se tornou uma espécie de "tabu" na Constituinte. Era contraditório que os parlamentares falassem em nome de uma democracia e atacassem os regimes arbitrários, mas, em contrapartida, não apoiassem a ampliação da anistia para aqueles que ainda viviam um exílio dentro da própria Pátria.

Devido aos debates de 18 de março e da polêmica em torno da entrevista de Prestes à Tribuna Popular, Otávio Mangabeira afirmou que a UDN não dava nenhum apoio ao PCB, estando pronta a cooperar com o governo do General Dutra na repressão das atividades comunistas. Os argumentos dos anticomunistas na Assembleia pareciam ter tornado o tema da anistia um tema proibido dentro do parlamento. Alguns parlamentares, como Acúrcio Torres do PSD, chegaram a afirmar que aquele era um tema que não cabia a Constituinte discutir, mas deveria ser discutido quando esta se dividisse em Câmara dos Deputados e Senado.

Euclides Figueiredo "compreendeu", após os debates de março, que a supressão das Comissões que julgariam cada caso daria ganho de causa aos comunistas. Entretanto, o deputado achava injusto pagar pelos erros dos comunistas e, para contornar o problema, Figueiredo readaptou sua 
indicação apresentando os artigos 34 e 35 das Disposições Transitórias. Em tais artigos o deputado concordava com a análise de caso por caso, porém pedia para que os "anistiados" aguardassem os pareceres das Comissões desempenhando seus respectivos cargos, caso o parecer fosse negativo, este deveria afastar-se do cargo. Euclides Figueiredo reconheceu a impossibilidade de remover os obstáculos à anistia ampla. $\mathrm{O}$ deputado admitiu a necessidade de Comissões para julgarem cada caso, pois o Brasil, segundo Figueiredo, assemelhava-se ao "cavalo de Troia", isto é, tinha o inimigo em seu bojo pronto para atacar traiçoeiramente (ANC, 04/06/46).

Como era de costume, a bancada do PCB foi uníssona em relação ao tema debatido, os 15 parlamentares, reunidos em torno de Luiz Carlos Prestes, foram unânimes ao se oporem aos artigos 34 e 35, uma vez que estes mantinham as comissões que julgariam cada caso. Porém, na Constituinte, esses já eram os únicos que clamavam por uma anistia ampla, nem mesmo o antigo Coronel da Velha República, Euclides Figueiredo, acreditava no êxito dessa proposta adequando-se à anistia "manca" proposta nesses artigos das Disposições Transitórias da Constituição de 1946. Contudo, nem isso foi possível.

Euclides Figueiredo, ao lançar o requerimento de anistia visava o esquecimento de sua participação na organização do assalto integralista ao palácio Guanabara em 1938. Euclides Figueiredo almejava a sua reversão às Forças Armadas. Entretanto, após os debates de março, ele percebeu o "perigo" representado pela ampliação da anistia; a medida seria um "presente de grego" que traria os "traidores da Pátria" em seu bojo.

Convencido do perigo, Figueiredo contentou-se com a anistia que o presidente Eurico Dutra concedeu-lhe individualmente logo após os debates de março. Euclides Figueiredo foi anistiado no posto de General do Exército em abril de 1946, após o recebimento do "prêmio" o novo General estava pronto para adequar-se às linhas da Constituinte e do presidente da República, agora era mais um a temer o "perigo comunista".

Apesar da imprevisibilidade de uma guerra entre o Brasil e URSS, as declarações de Prestes à Tribuna Popular deram um motivo para que aqueles homens de 1946, marcados, uns por rancores e outros temores, limitassem as liberdades individuais na nova Carta Constitucional.

Sem a ampliação da anistia, Prestes e seus "soldadinhos de chumbo" (MERGULHÃO, 1946) seguiriam como os indesejáveis da Pátria, os que não poderiam ser assimilados pelas Forças Armadas, os "traidores". Sobre o tema, Prestes declarou em 26 de março de 1946 na Constituinte: "Repete-se muito, nos dias de hoje, a palavra "traidor". Traidores - sabemo-lo bem - são todos os revolucionários vencidos. Traidores foram Tiradentes, o Frei Caneca." (ANC, 26/03/1946, p. 54).

Marcados pelo estigma da traição, os comunistas foram vítimas do passado e do futuro. Os acontecimentos de 1935 e 1945 não foram cicatrizados, portanto, para os Constituintes de 1946 a entrevista de Prestes à Tribuna Popular era apenas mais uma prova de que os comunistas eram os "traidores da Nação". 
Ressentidos, mas também temerosos em relação ao futuro, os udenistas preferiram abandonar o discurso democrático em relação à anistia para, assim, eliminarem a ameaça comunista do cenário político. Parafraseando João Neves da Fontoura, ao abrir mão da anistia, os liberais "deram os anéis para não perderem os dedos" (FONTOURA, 1978, p. 669).

Para depor Getúlio Vargas, em 1945, a UDN, sem o apoio dos Comunistas, teve de contar com o auxílio das Forças Armadas, entretanto, apesar do golpe de 29 de outubro de 1945, os "liberais" perderam as eleições presidenciais. Os comunistas, que já eram denominados de traidores desde 1935, ao não apoiarem a UDN contra o Estado Novo e, pelo contrário, ao apoiarem Getúlio Vargas em 1945, reforçaram sobre si o estigma da traição que se refletiu na Constituinte de 1946.

Para Luiz Carlos Prestes, o líder comunista, os udenistas não passavam de homens reacionários e golpistas que estavam sempre olhando para o passado. Portanto, ao deixar a prisão em 19 de abril de 1945, Prestes anunciou seu apoio ao governo e conclamou os comunistas a apoiarem o projeto democratizante de Vargas em fins do Estado Novo. Os udenistas não esqueceriam a "traição" de Prestes ao apoiar o governo que o mantivera encarcerado por nove anos, o governo que havia deportado sua esposa para a Alemanha nazista e exilado sua mãe.

A anistia foi o ponto culminante do acordo Prestes-Vargas, o Decreto de abril de 1945 era o prêmio recebido pelos comunistas por apoiarem Vargas. Entretanto, após a euforia dos primeiros meses, os "anistiados" perceberam que o Decreto-lei 7.474 assemelhava-se a mero indulto, uma vez que estavam à mercê de pareceres das Comissões nomeadas pelo presidente da República. Vargas estava ocupado o bastante com a ferrenha oposição liberal que ameaçava depô-lo, portanto, as Comissões de anistia, nomeadas por ele, quando chegaram a funcionar foi com extremo marasmo.

Os comunistas perceberam que não foram anistiados, mas simplesmente libertados das prisões varguistas para fazerem discursos em prol do ditador. Portanto, precisariam contar com a Constituinte de 1946 para ampliarem a anistia de 1945 e, em fim, receberem seu "prêmio". No entanto, como Prestes bem destacou, os liberais eram "reacionários" e não esqueciam, facilmente, o passado. Os liberais na Constituinte, ainda demonstravam ressentimentos em relação ao apoio que os comunistas deram a Vargas, além disso, alguns udenistas atribuíam a derrota do Brigadeiro Eduardo Gomes às atitudes de Prestes que o acusava de golpista e reacionário e, como se não fosse o bastante, Prestes lançara a candidatura de Fiúza para "prejudicar o candidato udenista" (LACERDA, 1987).

Além de rancorosos, os udenistas eram temerosos em relação ao futuro, não temiam apenas o retorno de Vargas, mas também o fortalecimento do comunismo que, após a participação da URSS na Segunda Guerra Mundial, tornara-se uma forte ameaça. Apesar de alguns parlamentares da UDN necessitarem da anistia, esses abriram mão do benefício para não possibilitarem o retorno dos comunistas às fileiras das Forças Armadas. Euclides Figueiredo, ao apresentar a indicação de ampliação da anistia, contrariou as diretrizes de seu partido, a UDN, entretanto, 
após a celeuma causada por seu discurso em março de 1946 na Constituinte, Euclides Figueiredo readaptou sua indicação de forma a não beneficiar diretamente os comunistas, mesmo assim sua proposta não foi aprovada e a anistia continuou restrita conforme o Decreto-lei de 1945.

$\mathrm{Na}$ Constituinte, as disputas pelo poder conduziram, também, as disputas de memória. Os parlamentares de 1946 se esforçaram para que o passado não fosse esquecido e acomodaram os acontecimentos pretéritos aos interesses contemporâneos. Nesse sentido, os comunistas foram condenados a carregarem o fardo do passado.

Diferentemente dos antigos gregos, que juravam não lembrar-se e nem permitir que outros o fizessem, os homens da "redemocratização" brasileira esforçaram-se na luta contra o esquecimento. E o "crime" dos comunistas tornou-se história.

\section{Abstract}

This text aims to analyze the time representation in the Constituent Assembly of 1946. For this, we have used like conductor line debates about Amnesty in that Assembly. The discourses about the theme evidence the tension between remembrance and forgetfulness, because parliamentarians, who self-called democrats, choose what have must to be forget, or not, through the amnesty. Hence, debates evidence apprehensions and resentments of parliamentarians who fought in two lines of battle: the past and de future.

Keywords: Amnesty. Assembly of 1946. Memory.

\section{Resumen}

El texto pretende analizar la representación del tiempo en la Asamblea nacional Constituyente de 1946. Para tanto, utilizamos como hilo conductor los debates sobre la Amnistía en aquella Asamblea. Los discursos referentes al tema revelan la tensión entre recuerdos y olvidos, una vez que los parlamentares, que llamaban a sí mismos demócratas, seleccionaban lo que debería ser olvidado, o no, través de la amnistía. Así, los debates revelan los temores y resentimientos de los parlamentares que luchaban en dos frentes de batalla: el pasado y el futuro.

Palabras-clave: Amnistía. Constituyente de 1946. Memoria.

\section{Notas}

1 Na Constituinte de 1946 os comunistas eram tratados como os indesejáveis, uma vez que eram tidos como traidores da Pátria devido ao levante de 1935 e à aliança com Vargas em 1945. Além disso, após o levante de 1935 surgiu a versão de que os comunistas teriam matado, covardemente, colegas legalistas que estavam dormindo, essa versão foi largamente utilizada pelos anticomunistas. Outro fato bastante utilizado pelos anticomunistas foi o assassinato de Elza Fernandes supostamente morta segundo ordens de Luiz Carlos Prestes.

2 Apesar de constantemente acusados de covardes, frios e traiçoeiros, a bancada do PCB na Assembleia não rechaçou a versão dos assassinatos em 1935.

3 Ao ser condenado pelo Tribunal de Segurança Nacional em 1938, Euclides Figueiredo perdeu sua patente de Coronel o que significava considerar o condenado como morto. Juridicamente, Figueiredo estava "morto" e coube à sua esposa uma pensão de viúva e aos seus filhos bolsas de estudos para alunos órfãos. 


\section{Bibliografia}

ALMINO, João. Os democratas autoritários. São Paulo: Brasiliense, 1980.

ANAIS DA ASSEMBLEIA NACIONAL CONSTITUINTE. Disponível em: <http:// imagem.camara.gov.br>. Acesso em: 20102011.

BRAGA, Sérgio Soares. Quem foi quem na Assembléia Constituinte de 1946. Um perfil socioeconômico e regional da Constituinte de 1946. Brasília: Câmara dos Deputados, 1988, 2 v.

CATROGA, Fernando. Memória e história. In: PESAVENTO, Sandra Jatahy (Org.). Fronteiras do milênio. Porto Alegre: Ed. UFRGS, 2001. p. 43-69.

CHATEAUBRIAND, Assis. O pensamento de Assis Chateaubriand. Artigos publicados em 1946. v. 23. Brasília, Fundação Assis Chateaubriand, 1999, $1.102 \mathrm{p}$.

FONTOURA, João Neves da. Discursos parlamentares. Brasília Câmara dos Deputados, 1978.

KOSELLECK, Reinhart. Futuro passado: contribuição à semântica dos tempos históricos. Rio de Janeiro: Contraponto: Ed. PUC - Rio, 2006.

LACERDA, Carlos. Depoimento. Rio de Janeiro: Nova Fronteira,1987.

. Na tribuna de imprensa: crônicas sobre a Constituinte de 1946. Sérgio Braga (Org.). Rio de Janeiro: Nova Fronteira, 2000.

LOWENTHAL, David. Como conhecemos o passado. In: Projeto História. Revista de estudos Pós-Graduandos em História do Departamento de História da Pontifícia Universidade Católica de São Paulo. v. 17, p. 63-201. 1998.

LUIS, Pedro. Para onde irá o comunismo? São Paulo: Nova Jurisprudência, [s/d]. na citação tem data 1946
MARTINS, Roberto Ribeiro. Liberdade para os brasileiros: anistia ontem e hoje. Rio de Janeiro: Civilização brasileira, 1978.

MARTINS, Estevão Rezende. Tempo e memória: a construção social da lembrança e do esquecimento. In: Liber Intellectus. Goiânia, v. 1, n. 1, junho 2007.

MERGULHÃO, Bendedicto. O bagageiro de Stálin. 2. ed., Rio de Janeiro: Editora Moderna, 1946.

MIRANDA, Yvonne de. Homens e fatos da Constituinte de 1946: memórias de uma repórter política. Rio de Janeiro: Argus, 1982.

MOTTA, Rodrigo Patto de Sá. Em guarda contra o "Perigo Vermelho": o anticomunismo no Brasil (1917-1964). São Paulo, Perspectiva: FAPESP, 2002 (Estudos; 180).

NETTO, Evaristo Giovanetti. (1986). O PCB na Assembléia Constituinte de 1946. São Paulo: Ed. Novos Rumos.

NOGUEIRA, Octaciano. A Constituinte de 1946: Getúlio, o sujeito oculto. São Paulo: Martins Fontes, 2005.

RICOEUR, Paul. A memória, a história, o esquecimento. Tradução: Alain François [et al.]. Campinas - SP: Editora da Unicamp, 2007.

RÜSEN, J. Como dar sentido ao passado: questões relevantes de meta-história. In: História da historiografia. n. 2, 2009.

VIANNA, Marly de Almeida Gomes. Revolucionários de 1935: sonho e realidade. São Paulo: Expressão Popular, 2007. 